\title{
Pure and Al-doped ZnO obtained by the modified Pechini method applied in ethanolic transesterification of cottonseed oil
}

\section{(ZnO puro e dopado com Al obtidos pelo método Pechini-modificado aplicado na transesterificação etanólica do óleo de algodão)}

\author{
M. F. Pereira, A. R. Silva-Neta, A. F. F. Farias, A. G. Souza, M. G. Fonseca, \\ L. F. B. L. Pontes, I. M. G. Santos* \\ Universidade Federal da Paraíba, Departamento de Química, LACOM, \\ Campus 1, João Pessoa, PB, Brazil 58051-970 \\ *ieda.garcia@pq.cnpq.br
}

\begin{abstract}
Pure zinc oxide $(\mathrm{ZnO})$ and 5\% Al-doped $\mathrm{ZnO}(\mathrm{ZNAL})$ were synthesized using the modified Pechini method and characterized by X-ray diffraction (XRD), X-ray fluorescence (XRF), Raman spectroscopy, infrared spectroscopy and UV-visible spectroscopy. XRF confirmed the theoretical stoichiometry, while XRD and Raman spectroscopy indicated that $\mathrm{Al}^{3+}$ was incorporated into the $\mathrm{ZnO}$ wurtzite lattice with no secondary phases, leading to a decrease in the band gap value and to a meaningful increase of the Lewis basic sites. Pure and doped $\mathrm{ZnO}$ were used as catalysts in the ethylic transesterification of cottonseed oil using a factorial design to determine the best synthesis conditions. Oil conversion into biodiesel was evaluated by viscosity measurements and ${ }^{1} \mathrm{H}$ NMR spectroscopy. The results analyzed by factorial design indicated that the catalyst type and temperature were the determinant factors in the conversion indices. The highest basicity of the ZNAL lead to a significant increase of the catalytic potential, reaching a reduction of the oil viscosity next to $71 \%$ at $130{ }^{\circ} \mathrm{C}$ and greater than $85 \%$ at $200{ }^{\circ} \mathrm{C}$.
\end{abstract}

Keywords: zinc oxide, doping, heterogeneous catalysis, biodiesel.

Resumo

Óxido de zinco puro (ZnO) e dopado com $5 \%$ de Al (ZNAL) foram sintetizados pelo método Pechini modificado e caracterizados por difração de raios $X(D R X)$, fluorescência de raios $X$ (FRX), espectroscopia Raman, espectroscopia no infravermelho e espectroscopia UV-visível. A análise por FRX confirmou a relação estequiométrica teórica, enquanto DRX e espectroscopia Raman indicaram que o $\mathrm{Al}^{3+}$ foi incorporado no retículo de wurtzita do ZnO sem fases secundárias, conduzindo a uma diminuição no valor do band gap e a um aumento significativo dos sítios básicos de Lewis. ZnO puro e dopado foram utilizados como catalisadores na transesterificação etanólica do óleo de algodão utilizando um planejamento fatorial para determinar as melhores condições de sintese. Os índices de conversão do óleo em biodiesel foram avaliados através de medidas da viscosidade e por espectroscopia $R M N^{1} H$. Os resultados analisados pelo planejamento fatorial indicaram que o tipo de catalisador e a temperatura foram os fatores determinantes nos índices de conversão. O aumento do caráter básico do catalisador ZNAL conduziu a um aumento significativo do potencial catalítico, atingindo uma redução da viscosidade do óleo próxima de $71 \%$ a $130{ }^{\circ} \mathrm{C}$ e superior a $85 \%$ a $200{ }^{\circ} \mathrm{C}$.

Palavras-chave: óxido de zinco, dopagem, catálise heterogênea, biodiesel.

\section{INTRODUCTION}

The increased concern over the environmental impact and increasing prices of petrol products, coupled with the fact that fossil fuels are non-renewable, has prompted a continuing search for fuels that are environmentally responsible energy sources, such as biodiesel [1-3]. The most commonly employed production route for this biofuel is the transesterification of vegetable oils and animal fats using catalysts $[4,5]$. Due to its reversibility, this type of reaction is strongly influenced by several factors including temperature, the size and polarity of the alcohol chain, the acidity of the oil, and the type and concentration of catalyst $[6,7]$. Different solids have been used as catalysts for biodiesel synthesis and the performance of these materials is directly linked to the nature of the acidic or basic sites found in their structures. The catalytic activity of solids having Lewis basic sites is dependent upon the interaction of the alcohol used as the transesterification agent with the surface of the catalyst. Alternatively, for Lewis acid catalysts, the carbonyl groups of the fatty materials interact with the surface, leading to the formation of carbocations $[6,7]$.

Zinc oxide is an amphoterous oxide and has been used as a catalyst for transesterification reactions in its pure form, mixed with other oxides or salts, or as a support or matrix for other substances [8-13]. Nascimento et al. [8] compared the efficiency of $\mathrm{ZnO}$ with $\mathrm{CaO}, \mathrm{CaTiO}_{3}$ and $\mathrm{TiO}_{2}$, which were all obtained by the polymeric precursor method. The 
use of $\mathrm{CaO}$ led to a high conversion of corn oil into methylic esters at $70{ }^{\circ} \mathrm{C}$ but resulted in high levels of Ca leaching into the biodiesel. Compared with the other oxides, a greater conversion was attained with $\mathrm{ZnO}$ at $150{ }^{\circ} \mathrm{C}$. Few papers report the effect of cation addition into the $\mathrm{ZnO}$ lattice (doping) on its catalytic activity for biodiesel synthesis. Recently, the doping of $\mathrm{Cu}$ into the $\mathrm{ZnO}$ lattice with a high conversion of waste cooking oil into methylic esters at $60^{\circ} \mathrm{C}$ was reported [9].

For the $\mathrm{ZnO}-\mathrm{Al}_{2} \mathrm{O}_{3}$ system, different papers report the catalytic activity of the $\mathrm{ZnAl}_{2} \mathrm{O}_{4}$ spinel $[10,11]$. For instance, Thirunavukkarasu et al. [10] deposited $\mathrm{Zn}$ on gamma- $\mathrm{Al}_{2} \mathrm{O}_{3}$ and on $\mathrm{Fe}_{2} \mathrm{O}_{3}$ and, after heat treatment at $600{ }^{\circ} \mathrm{C}$, observed the formation of $\mathrm{ZnAl}_{2} \mathrm{O}_{4}$ and $\mathrm{ZnFe}_{2} \mathrm{O}_{4}$, respectively. Both spinels are active in the methanolic transesterification of vegetable oils. In other research employing $\mathrm{ZnAl}_{2} \mathrm{O}_{4}$ as a catalyst, Pugnet et al. [11] evaluated different reaction parameters in the methanolic transesterification of rapeseed oil, with a conversion of approximately $80 \%$ at $200{ }^{\circ} \mathrm{C}$. Veiga et al. [12] obtained $\mathrm{ZnO}-\mathrm{Al}_{2} \mathrm{O}_{3}$ catalysts with different $\mathrm{Zn}: \mathrm{Al}$ ratios for the methylic transesterification of soybean oil. Al-doped $\mathrm{ZnO}$, synthesized with $25 \% \mathrm{Al}$, attained approximately $30 \%$ conversion at $130{ }^{\circ} \mathrm{C}$, much lower than conversions attained with $50 \% \mathrm{Al}$ (composed of $\mathrm{ZnO}$ and $\mathrm{ZnAl}_{2} \mathrm{O}_{4}$ ), which reached more than $80 \%$. Another interesting paper [13] reports the use of $\mathrm{Zn}$-doped $\mathrm{Al}_{2} \mathrm{O}_{3}(20$ $\mathrm{mol} \% \mathrm{ZnO}$ ) as a catalyst in the ethanolic and methanolic transesterification of soybean oil. The yield for the methanolic reaction at $100{ }^{\circ} \mathrm{C}$ was double that of the ethanolic reaction, which required a reaction temperature of $180^{\circ} \mathrm{C}$ to reach a $78 \%$ yield. The present work is aimed at obtaining biodiesel by the ethylic transesterification of vegetable oil using $\mathrm{ZnO}$ and $\mathrm{Al}$-doped $\mathrm{ZnO}$ catalysts synthesized using the modified Pechini method [14]. Despite its poor yield compared to methanol, the ethanolic route to avoid the use of petroleumderived precursors was utilized, obtaining a truly green fuel. Moreover, Brazil is a significant producer of ethanol.

\section{EXPERIMENTAL}

\section{Catalyst synthesis and characterization}

Pure $\mathrm{ZnO}$ was synthesized, via the modified Pechini method, by dissolution of $\mathrm{Zn}\left(\mathrm{NO}_{3}\right)_{2} \cdot 6 \mathrm{H}_{2} \mathrm{O}$ (Aldrich) in a stirred, aqueous citric acid (Cargill) solution at $70{ }^{\circ} \mathrm{C}$ using a citric acid:metal molar ratio of 3:1. After complete dissolution, ethylene glycol (Aldrich) was added to the solution, with a citric acid:ethylene glycol mass ratio of 6:4, and the temperature was increased to $90{ }^{\circ} \mathrm{C}$. The polymeric resin was heated at a rate of $2{ }^{\circ} \mathrm{C}$. $\mathrm{min}^{-1}$ and semicarbonized at $300^{\circ} \mathrm{C}$ for $2 \mathrm{~h}$. After heat treatment, the polymeric precursor was ground, passed through a 200 mesh $(74 \mu \mathrm{m})$ sieve, and heat treated in an air atmosphere at 600,700 and $800{ }^{\circ} \mathrm{C}$ for $4 \mathrm{~h}$ with a heating rate of $5{ }^{\circ} \mathrm{C} \cdot \mathrm{min}^{-1}$. The same procedure was adopted for $5 \% \mathrm{Al}$-doped $\mathrm{ZnO}$ (ZNAL), but using an aqueous solution comprising $\mathrm{Al}\left(\mathrm{NO}_{3}\right)_{3} \cdot 6 \mathrm{H}_{2} \mathrm{O}$ (Aldrich) and $\mathrm{Zn}\left(\mathrm{NO}_{3}\right)_{2} \cdot 6 \mathrm{H}_{2} \mathrm{O}$ (Aldrich).
X-ray diffraction (XRD) was performed on a Shimadzu XRD 6000 instrument using $\mathrm{K}_{\alpha}(\mathrm{Cu})$ radiation $(\lambda=1.5406 \AA)$, a step scan of $0.02^{\circ} \cdot \mathrm{s}^{-1}$ and a $2 \theta$ range of 3 to $80^{\circ}$. Patterns were compared to ICDD standards. X-ray fluorescence (XRF) measurements were performed on a Shimadzu XRF1800 spectrometer using internal standards for elemental quantification. UV-visible spectra were obtained with a Shimadzu UV-2550 spectrophotometer in reflectance mode between 190 and $900 \mathrm{~nm}$. Absorbance spectra were used to calculate the energy band gap according to the Wood and Tauc method [15]. Infrared spectra were obtained with a Shimadzu IRPrestige-21 spectrophotometer between 4000 and $400 \mathrm{~cm}^{-1}$, using $\mathrm{KBr}$ pellets. Raman spectra were recorded on a Renishaw InVia Raman spectrometer using a $100 \mathrm{~mW}$ Ar laser $(\lambda=514 \mathrm{~nm})$. Evaluation of the acidic or basic character of $\mathrm{ZnO}$ and $\mathrm{ZNAL}$ was performed by addition of $0.5 \mathrm{~g}$ of each catalyst into $10 \mathrm{~mL}$ of $\mathrm{HCl}$ or $\mathrm{KOH}$ solution $\left(0.005 \mathrm{~mol}^{\mathrm{L}} \mathrm{L}^{-1}\right)$ and measurement of the $\mathrm{pH}$ change at 6 min intervals for $1 \mathrm{~h}$ using a benchtop $\mathrm{pH}$ meter (Digimed DM22).

\section{Transesterification reaction}

A two level factorial design was proposed for the ethanolic transesterification of the cottonseed oil [16, 17]. The parameters of temperature, alcohol:oil ratio and catalyst type were evaluated over a $4 \mathrm{~h}$ reaction time. The low and high levels for each variable are presented in Table I. Experimental data were analyzed by the Statistica 8.0 software (Statistica for Windows 8.0, Statsoft, USA).

Transesterification reactions were performed in a Parr reactor, mod. 4842, with a maximum working pressure of 200 bar. Considering that this reaction proceeds via a basic catalytic mechanism, $50 \mathrm{~g}$ of commercial cottonseed oil were added to ethanol (Moderna) containing $3 \mathrm{wt} \%$ catalyst (with respect to the oil) in alcohol:oil ratios of $6: 1$ and 12:1. After the reaction, the suspension was centrifuged to separate the catalyst, and water was added to the liquid phase with a decantation balloon to facilitate separation of the glycerin, esters and acylglycerides. Samples were dried at $90{ }^{\circ} \mathrm{C}$ under vacuum. In order to evaluate the acidic catalytic mechanism, the reaction with the hardest conditions (200 ${ }^{\circ} \mathrm{C}$ and alcohol:oil ratio of 12:1) was repeated by addition of ethanol to the cottonseed oil containing $3 \%$ catalyst

Table I - Factorial design used in the ethanolic transesterification of cottonseed oil using temperature, alcohol:oil ratio and catalyst type as variables.

[Tabela I - Planejamento fatorial para a transesterificação etanólica do óleo de algodão utilizando temperatura, razão álcool/óleo e tipo de catalisador como variáveis.]

\begin{tabular}{ccc}
\hline Variable & - & Level \\
\hline Temperature $\left({ }^{\circ} \mathrm{C}\right)$ & 130 & 200 \\
Alcohol:oil (molar ratio) & $6: 1$ & $12: 1$ \\
Catalyst type & $\mathrm{ZnO}$ & ZNAL \\
\hline
\end{tabular}


( $\mathrm{ZnO}$ or $\mathrm{ZNAL})$. The products were isolated as described above. Evaluation of the viscosity of the reaction products was performed using a Julabo V18 viscometer with a Cannon Fenske glass capillary immersed in a water bath at $40{ }^{\circ} \mathrm{C}$. Characterization of the esters and acylglycerides was performed by ${ }^{1} \mathrm{H}$ NMR using a Varian Gemini 300BB spectrometer operating at a frequency of $200 \mathrm{MHz}$.

\section{RESULTS AND DISCUSSION}

\section{Catalyst characterization}

The XRD patterns (Fig. 1) indicate the formation of zinc oxide in $\mathrm{ZnO}$ and $\mathrm{ZNAL}$. Increasing the heat treatment temperature resulted in increased crystallinity of the powder.
All peaks were well defined, indicating a high degree of longrange order was attained and confirming that the modifiedPechini method was successful for this synthesis. All peaks were indexed according to a wurtzite hexagonal unit cell, space group P63mc, $\mathrm{C}_{6 \mathrm{v}}^{4}$ (ICDD standard 89-1397). After doping, a small dislocation of the peaks to larger angles, as well as peak broadening, was observed when compared with pure $\mathrm{ZnO}$ (Fig. 1c), which indicates a higher degree of long-range disorder is present. The lattice parameters for $\mathrm{ZnO}$ were calculated, and no meaningful variation of the unit cell size was observed, as $\mathrm{a}=3.25 \AA$ and $\mathrm{c}=5.20 \AA$ for all samples. According to the XRF results, the quantitative analysis of $\mathrm{Zn}$ reported $99.7 \%$ purity for the pure $\mathrm{ZnO}$ form. For the ZNAL, quantitative analysis reported 94.6 $\mathrm{mol} \% \mathrm{ZnO}$ and $4.9 \mathrm{~mol} \% \mathrm{Al}_{2} \mathrm{O}_{3}$, suggesting satisfactory
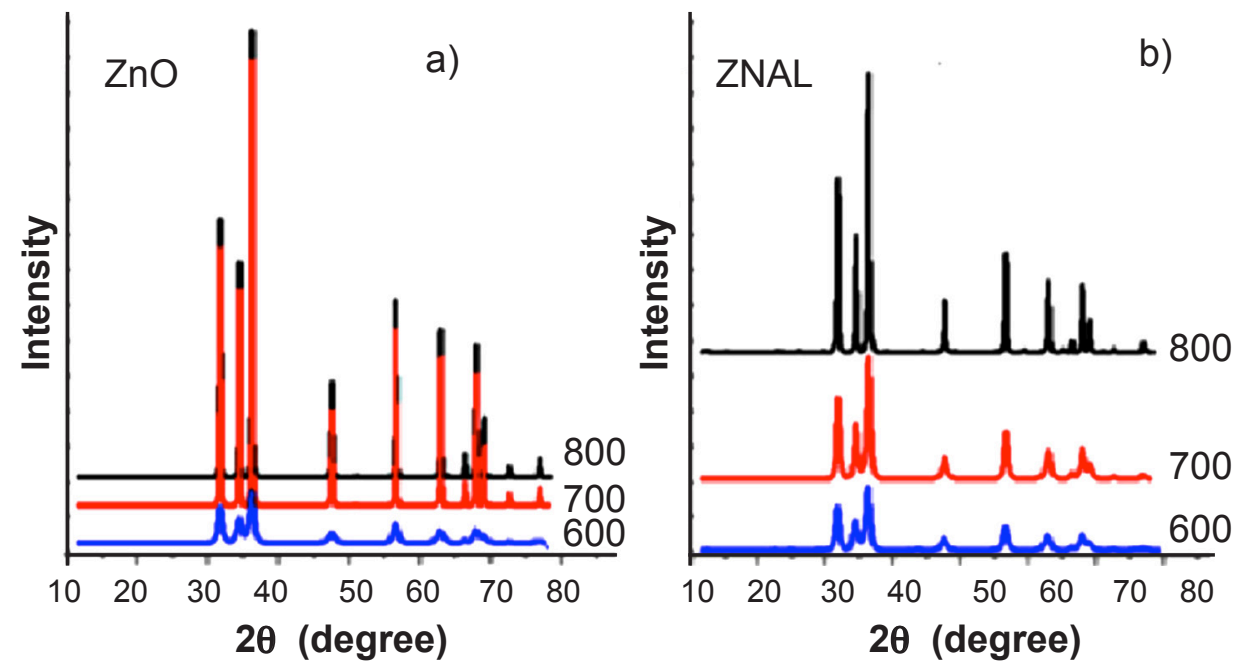

c)

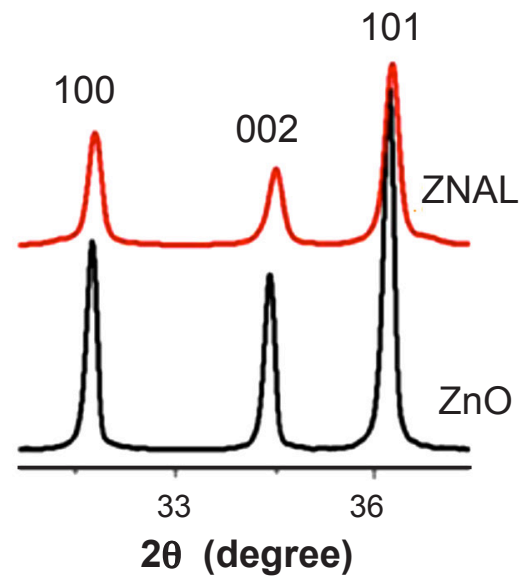

Figure 1: X-ray diffraction patterns of ZnO (a) and ZNAL (b) after firing at 600,700 and $800{ }^{\circ} \mathrm{C}$. In (c), enlargement of the XRD patterns between $30^{\circ}$ and $38^{\circ}$ for $\mathrm{ZnO}$ and ZNAL heat treated at $800{ }^{\circ} \mathrm{C}$.

[Figura 1: Difratogramas de raios X do ZnO (a) e ZNAL (b) após calcinação a 600, 700 e $800^{\circ} \mathrm{C}$. Em (c), ampliação dos difratogramas entre $30^{\circ}$ e $38^{\circ}$ para $\mathrm{ZnO}$ e ZNAL calcinados a $800^{\circ} \mathrm{C}$.]
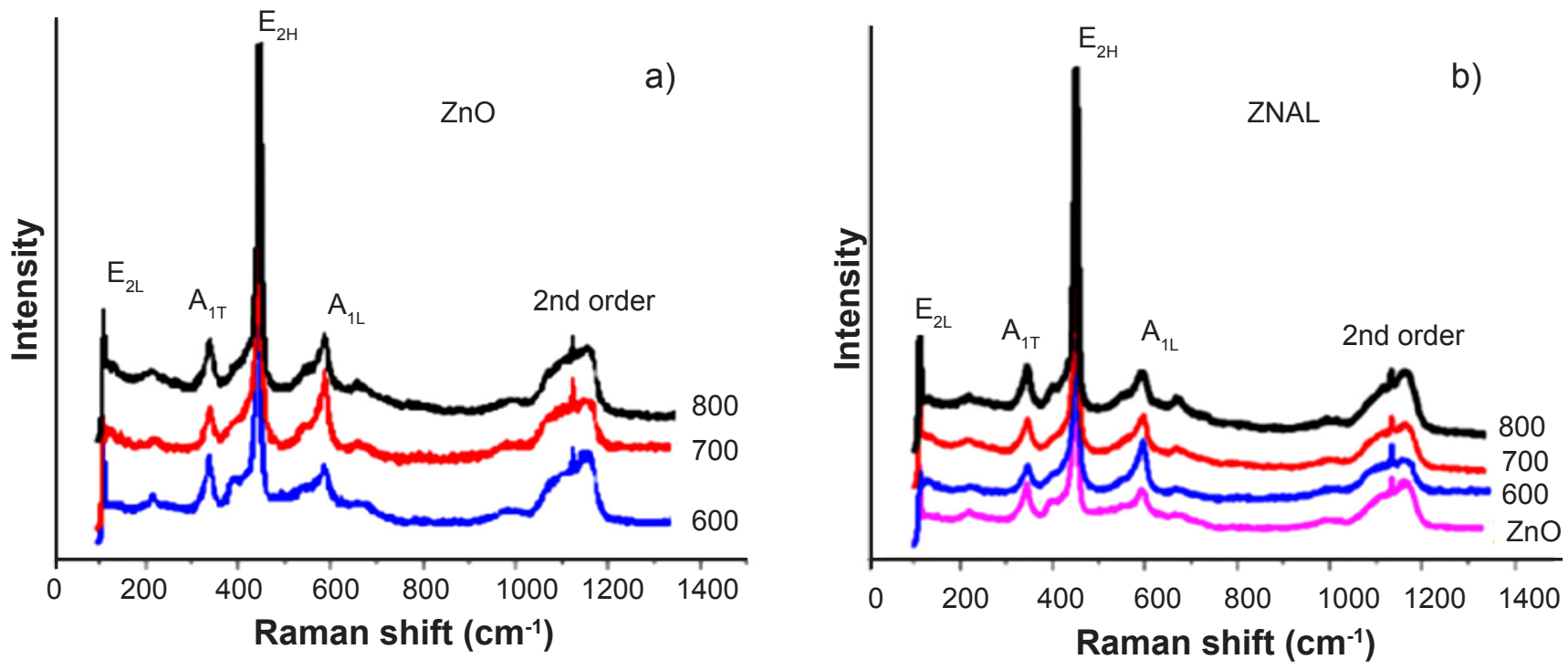

Figure 2: Raman spectra of $\mathrm{ZnO}(\mathrm{a})$ and $\mathrm{ZNAL}(\mathrm{b})$, heat treated at 600,700 and $800{ }^{\circ} \mathrm{C}$.

[Figura 2: Espectros Raman para o ZnO (a) e ZNAL (b), após calcinação a 600, 700 e $800^{\circ} \mathrm{C}$.] 

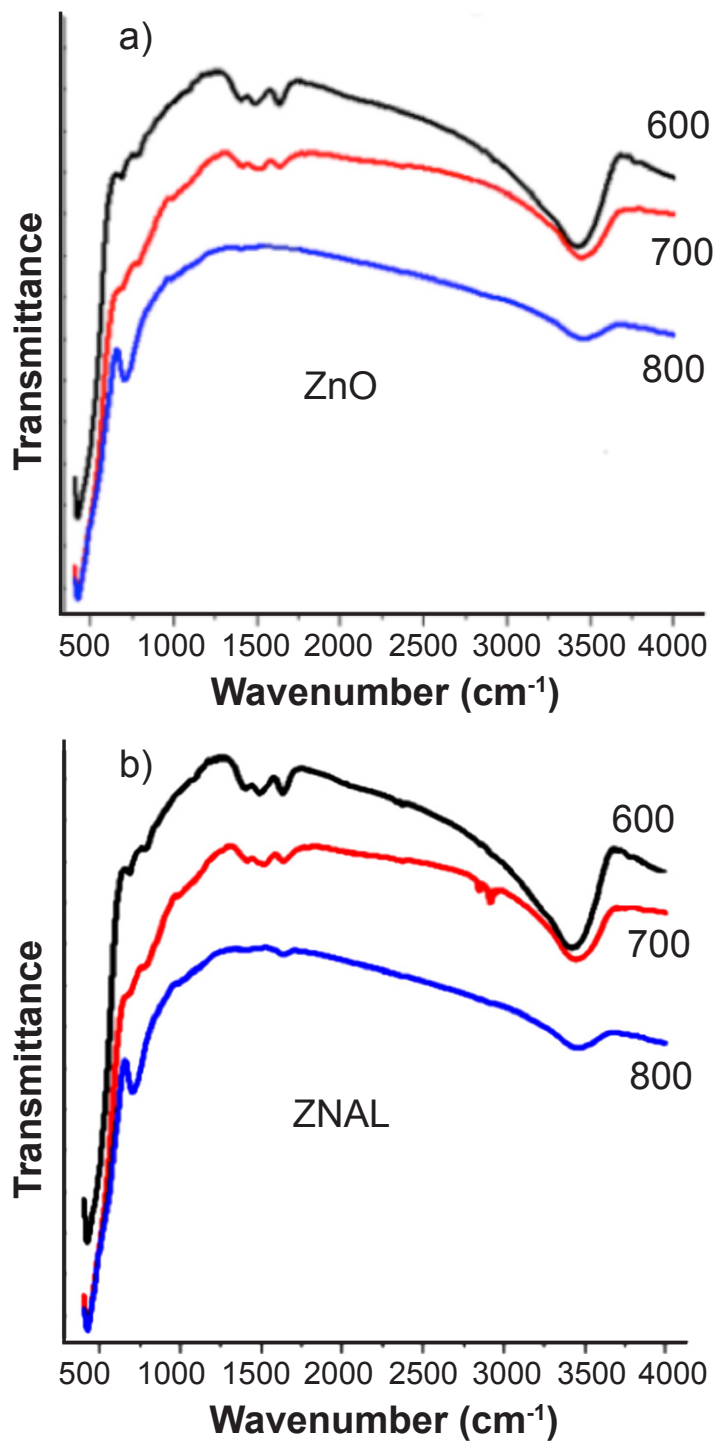

Figure 3: FTIR spectra of ZnO (a) and ZNAL (b), heat treated at 600,700 and $800^{\circ} \mathrm{C}$.

[Figura 3: Espectros FTIR do ZnO (a) e ZNAL (b), após calcinação a 600,700 e $\left.800^{\circ} \mathrm{C}.\right]$

stoichiometric control was attained.

Zinc oxide with a wurtzite structure belongs to the space group $\mathrm{C}_{6 \mathrm{v}}^{4}$, which has two formula units per unit cell, all atoms occupying $2 \mathrm{~b}$ sites with $\mathrm{C}^{3}{ }_{\mathrm{v}}$ symmetry and the following active modes in the Raman spectrum: $\mathrm{A}_{1}+$ $2 \mathrm{~B}_{1}+\mathrm{E}_{1}+2 \mathrm{E}_{2} \cdot \mathrm{A}_{1}$ and $\mathrm{E}_{1}$ are polar phonon modes, divided into transverse $\left(\mathrm{A}_{1 \mathrm{~T}}\right.$ and $\left.\mathrm{E}_{1 \mathrm{~T}}\right)$ and longitudinal $\left(\mathrm{A}_{1 \mathrm{~L}}\right.$ and $\left.\mathrm{E}_{1 \mathrm{~L}}\right)$ polar optical modes, while $\mathrm{E}_{2}$ consists of two high- and lowfrequency phonon modes $\left(\mathrm{E}_{2 \mathrm{H}}\right.$ and $\left.\mathrm{E}_{2 \mathrm{~L}}\right)$ [18-20]. The Raman spectra of $\mathrm{ZnO}$ and $\mathrm{ZNAL}$ are presented in Fig. 2. The bands at $101,339,388$ and $437 \mathrm{~cm}^{-1}$ were assigned to the wurtzite structure. The bands above $800 \mathrm{~cm}^{-1}$ were due to the second order Raman modes [19]. An additional band was observed at $221 \mathrm{~cm}^{-1}$, which is related to the presence of oxygen vacancies in the lattice [19-21]. These results confirm that both samples have hexagonal wurtzite structures with high degrees of short-range order, as additional bands are not observed after doping. Moreover, no meaningful changes in the spectra were observed, indicating that no symmetry breaking occurred.

The infrared spectra from 4000 to $400 \mathrm{~cm}^{-1}$ are presented in Fig. 3. The bands assigned to tetrahedrally coordinated $\mathrm{Zn}-\mathrm{O}$ or Al-O were observed between 400 and $500 \mathrm{~cm}^{-1}$, and the bands assigned to the stretching of tetrahedrally coordinated Me-O bonds were observed between 750 and $880 \mathrm{~cm}^{-1}[13,22]$. A well-defined band at $750 \mathrm{~cm}^{-1}$ was only obtained after heat treatment at $800{ }^{\circ} \mathrm{C}$, due to the high degree of short-range order. Bands at 3500 and $1635 \mathrm{~cm}^{-1}$ were also observed and assigned to the $\mathrm{OH}$ stretching and bending, respectively, of water molecules adsorbed on the material surface [23]. Small bands were observed between 1270 and $1490 \mathrm{~cm}^{-1}$ and were assigned to the carboxyl stretching frequencies, $v(\mathrm{C}=\mathrm{O})$ and $v(\mathrm{C}-\mathrm{O})$, respectively. These bands indicate that ester complexes were still present in the material after calcinations at 600 and $700{ }^{\circ} \mathrm{C}$ but were eliminated at $800{ }^{\circ} \mathrm{C}$ [24]. These results suggest an optimal heat treatment temperature of $800{ }^{\circ} \mathrm{C}$ for both samples.

The band gap values of the materials heat treated at $800{ }^{\circ} \mathrm{C}$ were calculated from the UV-vis absorption spectra (Fig. 4), according to the methodology described by [15], and the observed values were $3.2 \mathrm{eV}$ for pure $\mathrm{ZnO}$ and 2.9 eV for ZNAL. Similar results were obtained by Bel-HadjTahar and Mohamed [25], who observed a decrease in the band gap value when $\mathrm{ZnO}$ was doped with aluminum, and Mote et al. [26], who observed a decrease in the band gap value when $\mathrm{ZnO}$ was doped with yttrium. Bai et al. [23] evaluated the influence of Al-doping into $\mathrm{ZnO}$ by firstprinciple calculations. According to their results, band gap narrows because the conduction band undergoes a greater shift towards the low-energy region than the valence band.

Replacing a $\mathrm{Zn}^{2+}$ ion for $\mathrm{Al}^{3+}$ implies the need for charge compensation. According to [23, 27], this compensation is achieved through the introduction of electrons in the doped- $\mathrm{ZnO}$ conduction band, favored by the band gap narrowing, increasing concentration of free electrons. As

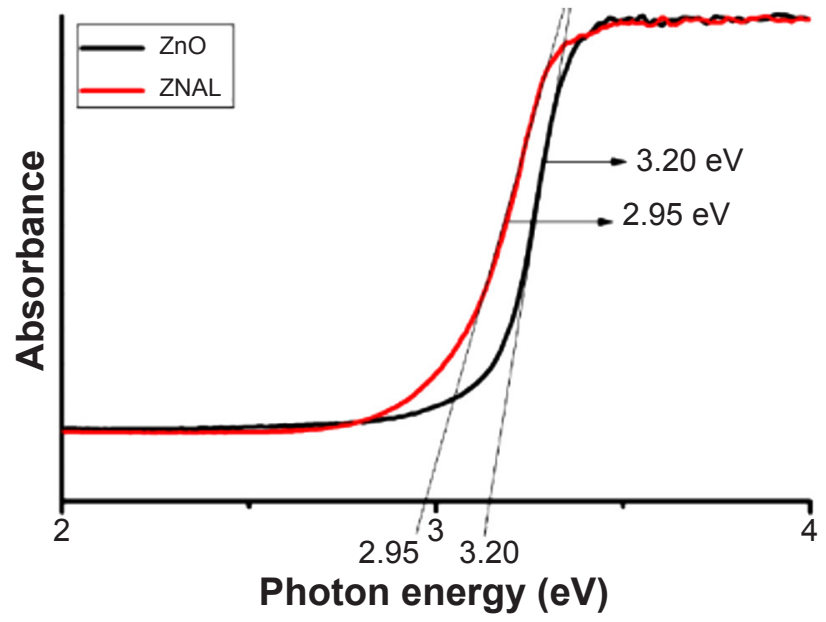

Figure 4: UV-Vis spectra of $\mathrm{ZnO}$ and $\mathrm{ZNAL}$, heat treated at $800{ }^{\circ} \mathrm{C}$. [Figura 4: Espectros UV-Vis do ZnO e ZNAL após calcinação a 600, 700 e $\left.800^{\circ} \mathrm{C}.\right]$ 
a consequence, an increase in conductivity and in sensing properties of the doped oxide have been observed [23, 27]. The charge compensation mechanism is presented in Equation A, written considering the Kröger-Vink notation [28]. This behavior may enhance the Lewis base character of the material, as electron donor defects $\left(\mathrm{Al}_{\mathrm{Zn}}{ }_{\mathrm{n}}\right)$ are formed.

$$
\mathrm{Al}_{2} \mathrm{O}_{3} \stackrel{\mathrm{ZnO}}{\longrightarrow} 2 \mathrm{Al}_{\mathrm{Zn}}^{\cdot}+2 \mathrm{e}^{\prime}+3 \mathrm{O}_{\mathrm{o}}^{\mathrm{x}}
$$

It is well known that $\mathrm{ZnO}$ is an amphoteric material. In order to understand the prevailing acid-base character and the influence of the Al-doping, adsorption of $\mathrm{OH}^{-}$and $\mathrm{H}_{3} \mathrm{O}^{+}$ species on the powder surfaces was evaluated for samples calcined at $800{ }^{\circ} \mathrm{C}$ (Fig. 5). $\mathrm{ZnO}$ and ZNAL samples exhibited higher basic character as indicated by the change in the $\mathrm{pH}$ value due to the $\mathrm{OH}^{-} / \mathrm{H}_{3} \mathrm{O}^{+}$adsorption/elimination. Al-doping increased the number of basic sites by more than
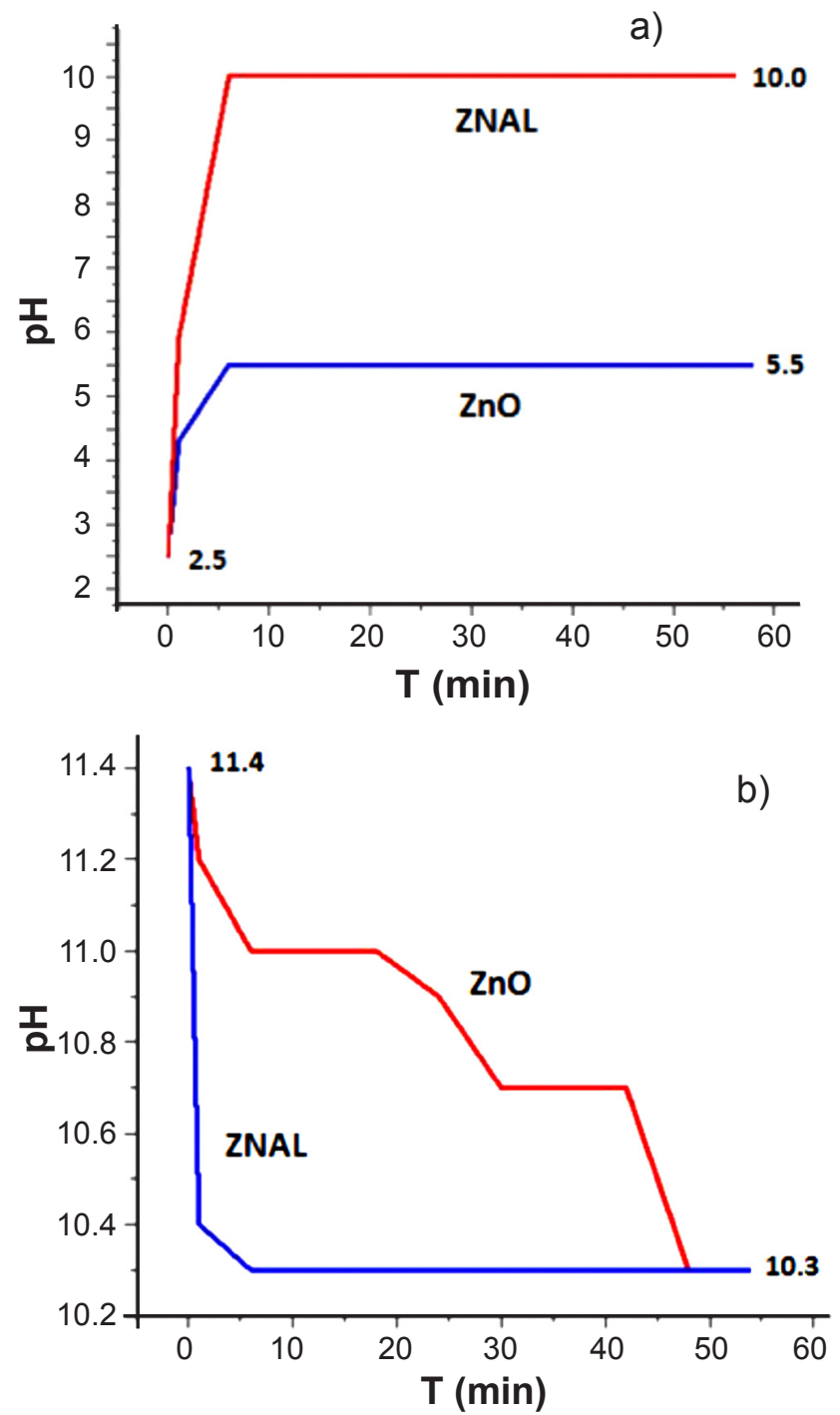

Figure 5: Evaluation of the acid/basic sites, for $\mathrm{ZnO}$ and ZNAL in acid (a) and basic medium (b).

[Figura 5: Avaliação dos sítios ácidos/básicos, para ZnO e ZNAL em meio ácido (a) e meio básico (b).]
4 orders of magnitude relative to pure $\mathrm{ZnO}$. In regard to the acidic character of the catalysts, Al-doping increased the kinetics of $\mathrm{OH}^{-}$adsorption onto the surface.

\section{Ethylic transesterification reaction}

Transesterification reactions occur in three consecutive steps through which triacylglycerides (TAG) are converted into fatty acid esters (R'COORx) and glycerol (GL). However, partial reactions can occur producing monoacylglycerides (MAG) and/or diacylglycerides (DAG) thus decreasing the overall ester content at the end of the reaction (Fig. 6) [29, 30].

Ethylic transesterification may proceed via an acid or a basic mechanism. In the heterogeneous catalysis by the

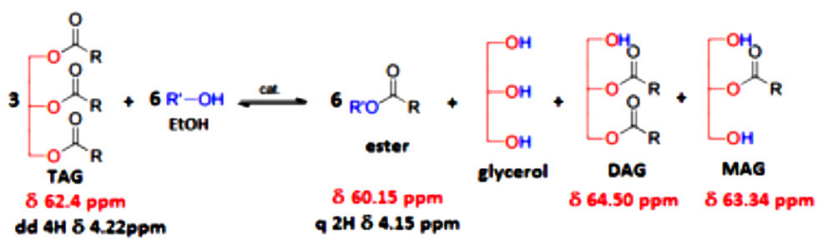

Figure 6: General equation for ethanolic transesterification of triglycerides, considering partial reaction, with the respective ${ }^{1} \mathrm{H}$ and ${ }^{13} \mathrm{C}$ NMR signals.

[Figura 6: Equação geral para transesterificação etanólica de triglicerídeos, considerando reações parciais com os respectivos sinais de $\mathrm{RMN}{ }^{1} \mathrm{He} \mathrm{e}^{13} \mathrm{C}$.]

basic mechanism, the formation of an alkoxide (active species) takes place by reaction of an alcohol adsorbed on a Lewis base. In the second step, the carbonyl group of the acylglycerides gradually undergoes nucleophilic attack by the alkoxide, forming a tetrahedral intermediate. From a rearrangement of these intermediates, the formation of an ester and other alkoxy takes place which, after deprotonation of the conjugate acid, regenerates the Lewis base. This mechanism occurs on until virtually all tri-, diand monoacylglicerydes are turned into alkyl esters and glycerol. In the acid mechanism the TAG adsorbs on the catalyst surface, with a greater acid/base interaction between the metal present in the catalyst structure and the pair of electrons from the oxygen of the carbonyl group causing an increase in the positive charge density on the carbon bonded to this oxygen, forming a carbocation which, in turn, undergoes a nucleophilic attack from the pair of electrons of the alcohol hydroxyl group, forming a tetrahedral intermediate. After elimination of the water molecule from this intermediate, a fatty ester and a DAG are formed and the catalyst is regenerated after desorption of the reaction products from the surface. MAG and glicerol are formed from similar processes [7].

As $\mathrm{ZnO}$ is an amphoterous solid, the type of reaction mechanism was evaluated by favoring the alcohol adsorption on the catalyst surface (basic mechanism) by mixing ethanol with the catalyst previously to the cottonseed oil addition; or favoring the TAG adsorption (acid mechanism) by adding 
Table II - Kinematic viscosities after catalytic reaction: $\mathrm{BC}$ - basic catalysis, and AC - acid catalysis. [Tabela II - Viscosidades cinemáticas após cada reação: BC - catálise básica e AC - catálise ácida.]

\begin{tabular}{ccccc}
\hline \multirow{2}{*}{ Catalyst } & Temperature $\left({ }^{\circ} \mathrm{C}\right)$ & Ethanol:oil ratio & $\begin{array}{c}\text { Kinematic viscosity at } 40{ }^{\circ} \mathrm{C} \\
(\mathrm{cSt})\end{array}$ & $\begin{array}{c}\text { Viscosity reduction } \\
(\%)\end{array}$ \\
\hline \multirow{3}{*}{ ZnO (BC) } & 130 & $6: 1$ & 16.6 & 56.8 \\
& 130 & $12: 1$ & 14.5 & 85.5 \\
\multirow{2}{*}{ ZnO (AC) } & 200 & $6: 1$ & 8.7 & 77.3 \\
& 200 & $12: 1$ & 8.2 & 78.6 \\
ZNAL (BC) & 130 & $12: 1$ & 13.7 & 64.3 \\
\hline \multirow{2}{*}{ ZNAL (AC) } & 130 & $6: 1$ & 11.2 & 70.8 \\
& 200 & $6: 1$ & 9.2 & 76.0 \\
\hline
\end{tabular}

the catalyst into the oil with subsequent addition of alcohol. Reactions were done at the same conditions $-200{ }^{\circ} \mathrm{C}$ for 4 $\mathrm{h}$, ratio alcohol:oil of 12:1. Results are presented in Table II, which confirm that $\mathrm{ZnO}$ catalyzes the transesterification reaction by both mechanisms - the acid one or the basic one, with a higher efficiency for the basic mechanism, leading to a higher viscosity reduction. After Al-doping, only the basic mechanism is observed, and no conversion is attained when the reaction is performed under acid catalysis conditions. This result is in agreement with the highest basic character of $\mathrm{ZnO}$ and ZNAL, demonstrated in Fig. 5. For this reason, all other reactions were done with a previous mixture of the alcohol with the catalyst.

The experimental parameters of temperature, alcohol:oil ratio and catalyst type were used as variables in the factorial design to evaluate the conversions of the catalyzed transesterification reactions, as shown in Fig. 7. The significance of each variable and the possible interactions among them were evaluated by variance analysis (ANOVA) based on the Pareto graph (Fig. 7), which was plotted based on the values of the reductions in viscosities. The response surface (Fig. 8) was also used to obtain information about the experiments. According to the viscosity results (Table II), it was observed that the cottonseed oil has a kinematic viscosity of $38.4 \mathrm{cSt}$, which was reduced by 56.8 to $85.7 \%$ after the catalytic test, indicating that esters, MAG and/or DAG were formed. According to the Pareto graph (Fig. 7), the variance analysis and the response surface, the temperature produced the most significant positive effect, with the highest conversions obtained at higher temperature (200 ${ }^{\circ}$ C). The response surface (Fig. 8) indicates that a $21.35 \%$ increase in conversion was attained when the temperature was increased from the inferior level $\left(130^{\circ} \mathrm{C}\right)$ to the superior level $\left(200{ }^{\circ} \mathrm{C}\right)$. For the catalyst type, higher conversions were achieved when ZNAL (superior level) was used at all temperatures (Table II). A 15.6\% increase in conversion was attained when changing from the inferior level (pure $\mathrm{ZnO}$ ) to the superior level (ZNAL), as indicated by the response surface. These results confirm the importance of the highest

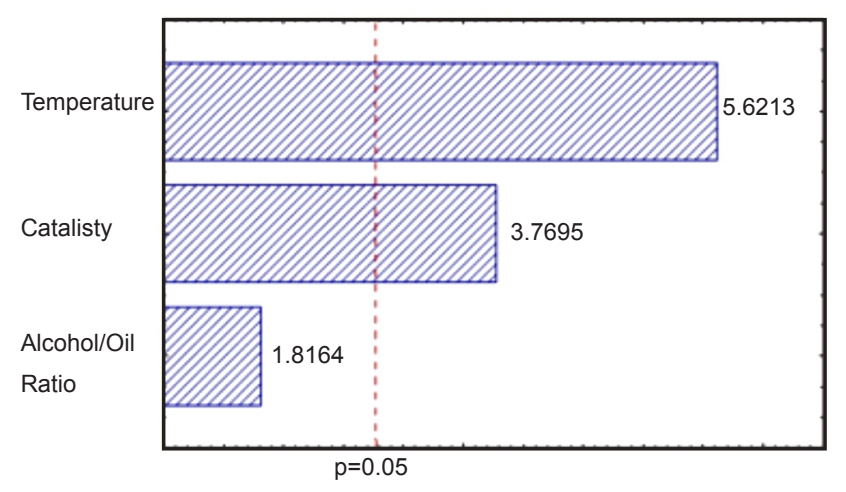

Figure 7: Evaluation of the ethanolic transesterification reaction of cotton seed oil via Pareto graphic of the $2^{3}$ factorial design - the vertical line defines the $95 \%$ of confidence range.

[Figura 7: Avaliação das reações de transesterificação etanólica do óleo de algodão através do gráfico de Pareto resultante do planeamento fatorial $2^{3}$. A linha vertical define um intervalo de confiança de $95 \%$.]

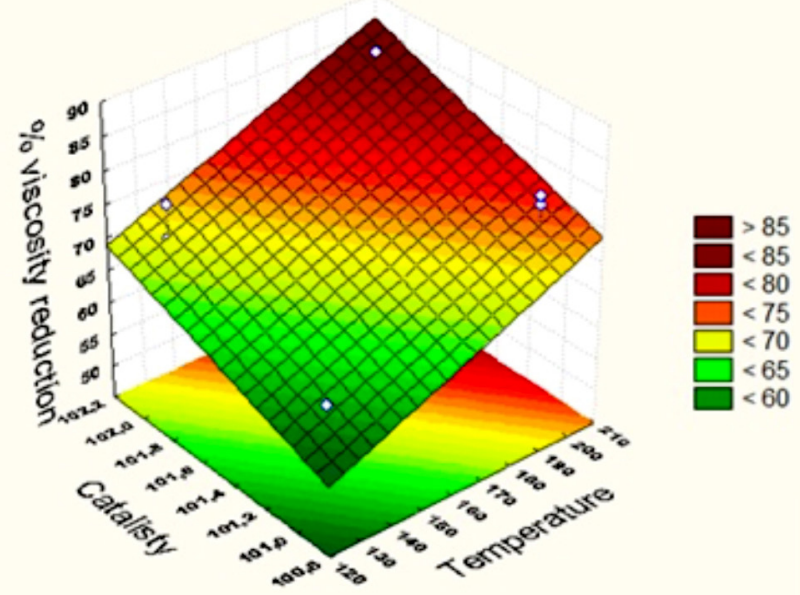

Figure 8: Response surface, considering level changes of temperature, alcohol:oil ratio, and catalyst type.

[Figura 8: Superficie de resposta, considerando temperatura, relação álcool:óleo e tipo de catalisador.] 


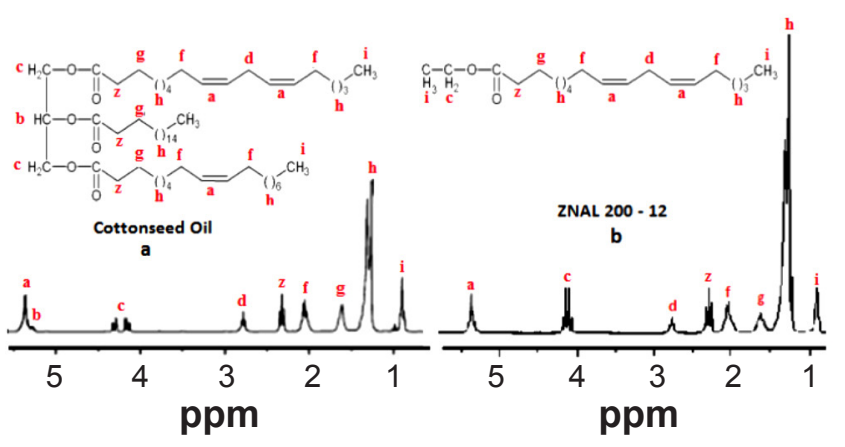

Figure 9: ${ }^{1} \mathrm{H}$ NMR spectra of the cotton seed oil (a) and of the ethyl ester obtained after ethanolic transesterification reaction using ZNAL with reaction at $200{ }^{\circ} \mathrm{C}$ and alcohol:oil ratio of 12:1 (b). [Figura 9: Espectros RMN ${ }^{1}$ H para o óleo de algodão (a) e para o etil éster resultante da reação de transesterificação catalisada por ZNAL na temperatura de $200^{\circ} \mathrm{C}$ e relação álcool:óleo 12:1 (b).]

Lewis basic character promoted by Al-doping into the $\mathrm{ZnO}$ lattice, indicated by Equation A and Fig. 5. Santos et al. [31] also observed a positive effect of doping in the synthesis of biodiesel. In this work, $\mathrm{ZnAl}_{2} \mathrm{O}_{4}$ spinel was doped with $\mathrm{Eu}^{3+}$, leading to a meaningful increase in the soybean oil conversion into biodiesel.

Each of the species involved in the transesterification reaction have characteristic signals in the ${ }^{1} \mathrm{H}$ NMR spectra that can be utilized to demonstrate the conversion of TAG into esters. For the ${ }^{1} \mathrm{H}$ NMR spectrum, the doublet of doublets (dd) with an integration of $4 \mathrm{H}$ appearing between $\delta 4.2$ and 4.4 ppm is assigned to the $\alpha-\mathrm{CH}_{2}$ group of TAG and is converted into a quartet (q) with an integration of $2 \mathrm{H}$ appearing between $\delta 4.0$ and $4.2 \mathrm{ppm}$, which corresponds to the $-\mathrm{CH}_{2} \mathrm{CH}_{3}$ ethyl ester group $[32,33]$. This difference in the spectrum profile can be observed for the cottonseed oil and the reaction products obtained using ZNAL at $200{ }^{\circ} \mathrm{C}$ (Fig. 9).

\section{CONCLUSIONS}

The Pechini method was efficient for the synthesis of zinc oxide in its pure form or doped with $5 \% \mathrm{Al}^{3+}$ with good stoichiometric control. Characterization indicated that $\mathrm{Al}^{3+}$ ions were incorporated into the $\mathrm{ZnO}$ crystalline lattice. The addition of $5 \% \mathrm{Al}^{3+}$ into zinc oxide maximizes its basic sites, driving the transesterification of cottonseed oil to a basic mechanism. The study of the experimental design indicated that adding $5 \% \mathrm{Al}^{3+}$ into the $\mathrm{ZnO}$ lattice significantly improved its application as a catalyst for the ethylic transesterification of cottonseed oil while temperature was also a determinant factor in the conversion rates of these reactions. The reduction in kinematic viscosity values associated with the characterization of the products by ${ }^{1} \mathrm{H}$ NMR confirmed the success of the transesterification reaction with triacylglycerides (TAG) conversion into esters.

\section{ACKNOWLEDGEMENTS}

This work is supported by Brazilian Funding Agencies:
CAPES/MCTI, CT-PETRO - CNPq/MCTI, FINEP/MCTI and INCT/CNPq/MCTI.

\section{REFERENCES}

[1] E. Lotero, J.G. Goodwin Jr., D.A. Bruce Jr., K. Suwannakarn, Y. Liu, D.E. Lopez, Catal. 19, 1 (2006) 41. [2] U. Schuchardt, R. Sercheli, R.M. Vargas, J. Braz. Chem. Soc. 9, 3 (1998) 199.

[3] R. Wang, M.A. Hanna, W.W. Zhou, P.S. Bhadury, Q. Chen, B.A. Song, S. Yang, Bioresource Technol. 102, 2 (2011) 1194.

[4] F. Ma, M.A. Hanna, Bioresource Technol. 70, 1 (1999) 1.

[5] M. Balat, Energy Convers. Manage. 52, 2 (2011) 1479.

[6] E.F. Aransiola, T.V. Ojumu, O.O. Oyekola, T.F. Madzimbamuto, D.I.O. Ikhu-Omoregbe, Biomass Bioenergy 61 (2014) 276.

[7] C.S. Cordeiro, F.R. da Silva, F. Wypych, L.P. Ramos, Quim. Nova 34, 3 (2011) 477.

[8] G.S. do Nascimento, G.P. Mambrini, E.C. Paris, J.A. Peres, L.A. Colnago, C.J. Ribeiro, J. Mater. Res. 27, 23 (2012) 3020 .

[9] B. Gurunathan, A. Ravi, Bioresource Technol. 188 (2015) 124

[10] K. Thirunavukkarasu, T.M. Sankaranarayanan, A. Pandurangan, R.V. Shanthia, S. Sivasankera, Catal. Sci. Technol. 4, 3 (2014) 851.

[11] V. Pugnet, S. Maury, V. Coupard, A. Dandeu, A.G. Quoineaud, J.L. Bonneau, D. Tichit, Appl. Catal. A-Gen. 374 (2010) 71.

[12] P.M. Veiga, A.S. Luna, M.F. Portilho, C.O. Veloso, C.A. Henriques, Energy 75 (2014) 453.

[13] F.M. Silva, D.M.M. Pinho, G.P. Houg, I.B.A. Reis, M. Kawamura, M.S.R. Quemel, P.R. Montes, P.A.Z. Suarez, Chem. Eng. Res. Des. 92, 8 (2014) 1463.

[14] H. Serier, A. Demourgues, J. Majimel, M. Gaudon, J. Solid State Chem. 184, 6 (2011) 1523.

[15] D.L. Wood, J. Tauc, Phys. Rev. B5 (1972) 3144.

[16] C.F.C. Neves, M.M.A.M. Schvartzman, Quím. Nova 25, 2 (2002) 327.

[17] M. Charoenchaitrakool, J. Thienmethangkoon, Fuel Process. Technol. 92, 1 (2011) 112.

[18] F. Decremps, J. Pellicer-Porres, A.M. Saitta, J.C. Chervin, A. Polian, Phys. Rev. B 65, 9 (2002) 092101.

[19] A. Khan, J. Pak. Mater. Soc. 4, 1 (2010) 5.

[20] S.J. Tark, Y.W. Ok, M.G. Kang, H.J. Lim, W.M. Kim, D. Kim, J. Electroceram. 23 (2009) 548.

[21] K. Mcguire, Z.W. Pan, Z.L. Wang, D. Milkie, J. Menéndez, A.M. Rao, J. Nanosci. Nanotech. 2, 5 (2002) 499.

[22] V. Parthasarathi, G. Thilagavathi, Int. J. Pharm. Pharm. Sci. 3, 4 (2011) 392.

[23] S. Bai, T. Guo, Y. Zhao, R. Luo, D. Li, A. Chen, C.C. Liu, J. Mater. Chem. A, 1 (2013) 11335.

[24] K. Nakamoto, Infrared and Ramam Spectra of Inorganic and Coordination Compounds, Jonh Wiley \& 
Sons, New York (1986).

[25] R. Bel-Hadj-Tahar, A.B. Mohamed, New J. Glass Ceram. 4 (2014) 55.

[26] V.D. Mote, Y. Purushotham, R.S. Shinde, S.D. Salunke, B.N. Dole, Cerâmica 61, 360 (2015) 457.

[27] M. Hjiri, L. El Mir, S.G. Leonardi, A. Pistone, L. Mavilia, G. Neri, Sens. Actuators, B-Chem. 196 (2014) 413.

[28] L.S. Mende, J.L.M. Driscoll, Mater. Today 10, 5 (2007) 40.

[29] R. Guzatto, D. Defferrari, Q.B. Reiznautt, I.R. Cadore,
D. Samios, Fuel 92 (2012) 197.

[30] N. Siddiqui, J. Sim, C.J.L. Silwood, H. Toms, R.A. Iles, M. Grootveld, J. Lipid. Res. 44, 12 (2003) 2406.

[31] P.T.A. Santos, P.M.A.G. Araújo, A.S. Silva, F.N. Silva, A.C.F.M. Costa, Cerâmica 61, 357 (2015) 110.

[32] J.L.N. Fernandes, R.O.M.A. Souza, R.B.V. de Azeredo, Magn. Reson. Chem. 50, 6 (2012) 424.

[33] A.F.F. Farias, K.F. Moura, J.K.D. Souza, R.O. Lima, J.D.S.S. Nascimento, A.A. Cutrim, E. Longo, A.S. Araujo, J.R. Carvalho Filho, A.G. Souza, I.M.G. Santos, Fuel 160 (2015) 357.

(Rec. 21/03/2016, Rev. 02/06/2016, Ac. 21/06/2016) 